\section{State-of-the-art technique to conduct in situ stress measurements in deep proposed coal-mining blocks of Singareni collieries, India}

\author{
D. S. Subrahmanyam*, G. Shyam, \\ K. Vamshidhar and S. Vikram \\ Geotechnical Engineering Department, National Institute of Rock \\ Mechanics, Bengaluru 560 070, India
}

\begin{abstract}
Singareni Collieries Company Ltd is proposing some new mining blocks in the Godavari coalfield with status document with roof hazard zonation maps vis-àvis stress field, for safe and economical mine design. Hence, National Institute of Rock Mechanics, conducted stress measurements by hydraulic fracturing method in the newly proposed mining blocks at Mandamarri and Bellampalli areas of Singareni collieries at deeper levels from the surface up to $600 \mathrm{~m}$ depth to find out the existing stress regime to prepare the roof hazard maps for safe and economic mining. This communication deals with the technique adopted for hydraulic fracturing, method of estimating stresses, analysis of the results for magnitude and direction of in situ stresses prevailing at deeper horizons. These studies could be helpful in other coal mining areas.
\end{abstract}

Keywords: Coal mining, hydraulic tests, pre-existing fracture, rock masses, stress.

IN general, the rock masses are primarily stressed in their native state described considering them to be continuous rather than an assemblage of detached particles. At every point, the stress is characterized by a second-order symmetric Cartesian tensor with six components. It cannot be assessed directly, but can only be assumed by disturbing the rock mass ${ }^{1}$. Stresses in rock masses arise from gravity and tectonics affecting the rock mass within the earth.

Geologically, the Singareni coalfields belong to Pranahita-Godavari valley basin, Telangana, India. Based on geological and structural set-up and the nature of the lithic fill, it is known as the Godavari Gondwana graben. Recent overcoring measurements across a graben fault system in a coal mine in Utah, USA showed the occurrence of abnormally high horizontal and vertical stresses. Longwall mining operations across the graben were accompanied by excessive floor heave in the tail gate. Anomalous stresses associated with local geological structures are probably widespread covering large mining areas. They can significantly impact mine stability and increase operational costs.

Hydraulic fracturing technique has been used in Indian coal mines at a depth of $600 \mathrm{~m}$ for the determination of

*For correspondence. (e-mail: subbu3268@gmail.com) principal stresses and also for the preparation of roof hazard maps for proper planning of excavation of future mining blocks at the Singareni collieries. Details of geology of the area, drilling of boreholes, methodology and determination of in situ stress parameters are provided in this communication.

The Singareni coalfields largely follow the course of the Pranahita and Godavari rivers. The PranahitaGodavari valley coalfield defines a north-northwestsouth-southeast trending basin on a Precambrian platform. It is located within the $350 \mathrm{~km}$ course of the Pranahita and the Godavari rivers (Figure 1).

On the basis of geological and structural set-up, and the nature of the lithic fill, the Godavari Gondwana graben is divided broadly into four sub-basins: (i) Godavari sub-basin, (ii) Kothagudem sub-basin, (iii) Chintalapudi sub-basin and (iv) Krishna-Godavari coastal sub-basin in Telangana (Figure 2). Further, they are divided into 11 coal belts.

Two sites were selected at the vicinity of the proposed mining blocks, viz. Mandamarri shaft block (MMSB) and Ravindrakhani Newtech (RKNT) dipside block for drilling two NX size (76 mm diameter) boreholes, marked KK244B in the MMSB block and RKP-801 in the RKNT dipside block, to $600 \mathrm{~m}$ depth. The sequence of drilling operations was as follows:

(a) Non-coring drilling with $96 \mathrm{~mm}$ polycrystalline diamond bit up to $462 \mathrm{~m}$.

(b) PX casing (140.7 $\mathrm{mm}$ outer diameter) lowered up to $30 \mathrm{~m}$.

(c) Lowered HQ $88.9 \mathrm{~mm}$ outer diameter rods up to $462 \mathrm{~m}$.

(d) Core drilling with BQ double-tube core barrel (55.9 mm outer diameter for collecting BX size cores of $36.4 \mathrm{~mm}$ diameter) assembly up to $582 \mathrm{~m}$.

(e) Reamed with BQ rod bit (56.6 mm outer diameter) after every 4 or 5 runs, i.e. $12-15 \mathrm{~m}$ core drilling with BQ core barrel.

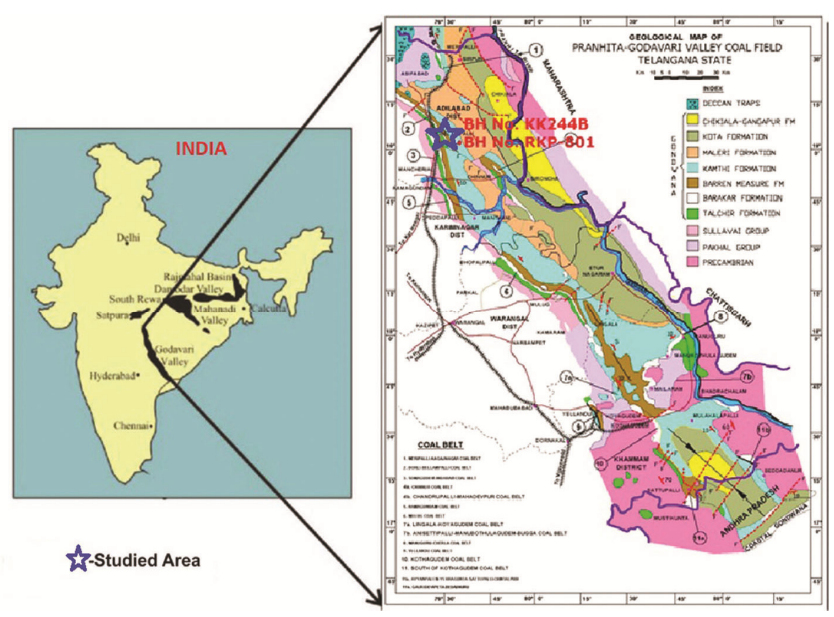

Figure 1. Location of experimental sites. 
(f) After completion of borehole reamed with NQ rods fitted with $\mathrm{BX}$ casing $\mathrm{TC}$ drill bit $(76 \mathrm{~mm}$ outer diameter) for lowering of packer (for hydraulic fracturing tests) and acoustic borehole televiewer (to obtain fracture traces).

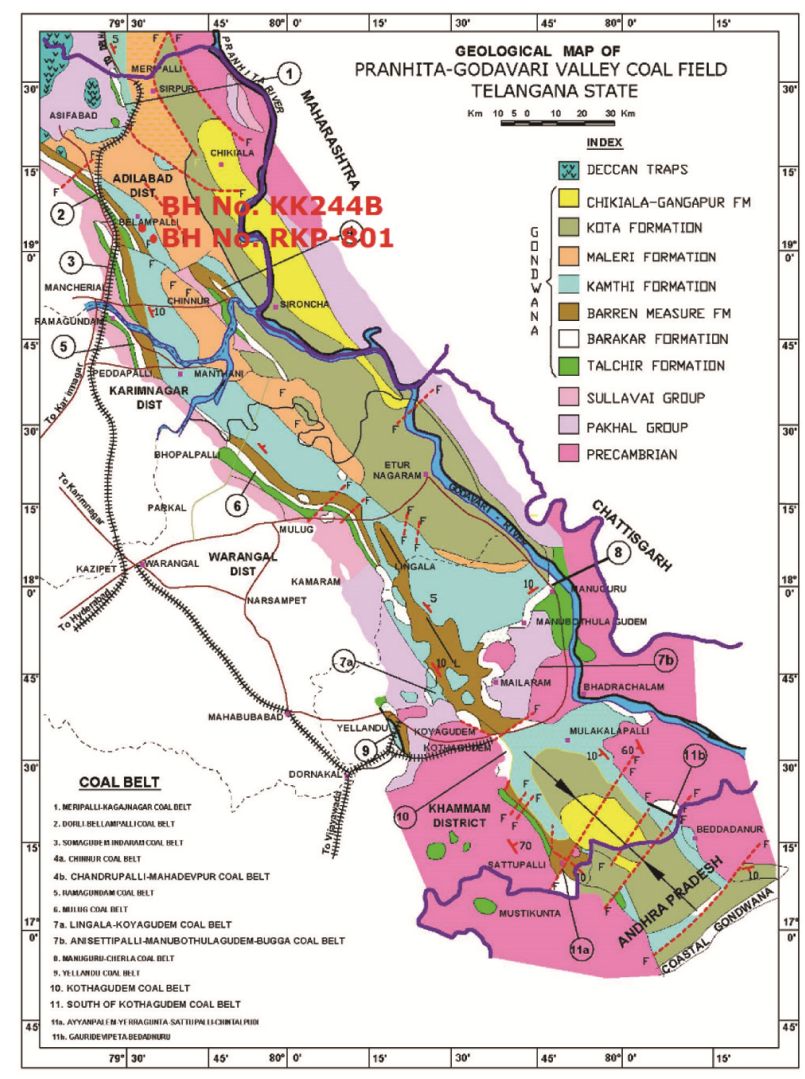

Figure 2. Map of Godavari valley coalfield, Telangana, India.

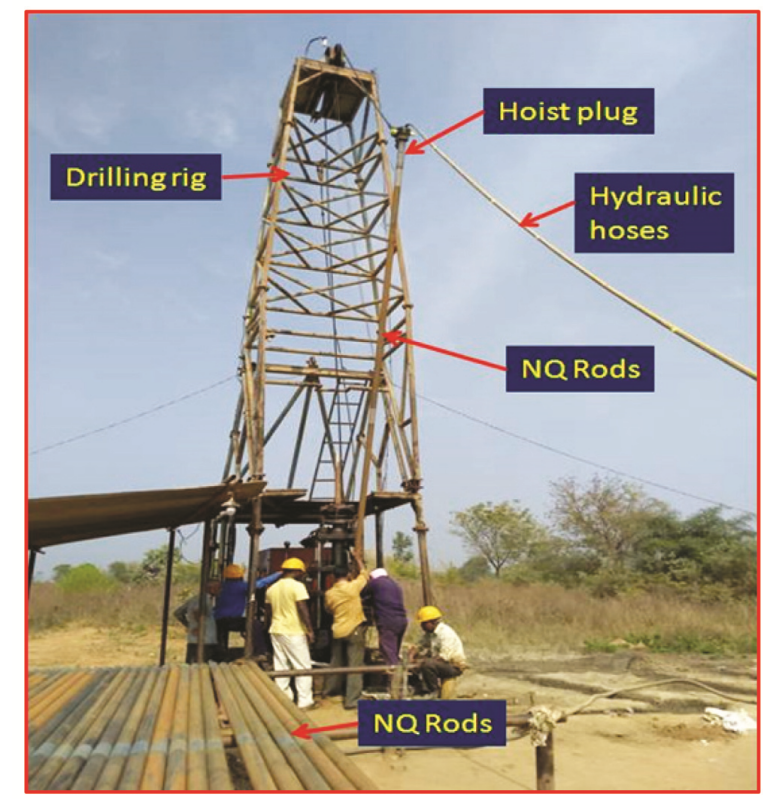

Figure 3. Lowering of the deep hole hydrofrac system.
Hydraulic fracturing is the only rock stress determination technique that has been successfully applied to deep drill holes ${ }^{2,3}$. This test gives the magnitude and orientation of principal stresses. The hydro-fracturing data interpretation technique and its limitations for the current site conditions are discussed later in the text. Rock strata do not influence data interpretation technique; but it may cause fracturing decay due to presence of pores. Hence fracturing by high flow rate fulfils the requirement.

The hydraulic fracturing assembly comprises two steelreinforced packer elements, each of $70 \mathrm{~mm}$ OD and $635 \mathrm{~mm}$ length (Figure 3). An impression packer of $123.5 \mathrm{~cm}$ length (Inflatable Packers International (IPI), Australia) was used for taking impressions after fracturing. The test interval length was $350 \mathrm{~mm}$.

Two high-pressure hoses of 9.8 and $6.4 \mathrm{~mm}$ inner diameter with working pressure $78 \mathrm{MPa}$ and burst pressure of $280 \mathrm{MPa}$ is used for fluid flow. The flow rate was $10 \mathrm{l} / \mathrm{min}$ during pressurization. Pressure was controlled by a flow control system based on $6 \mathrm{~mm} / 12 \mathrm{~mm}$ tubes and fittings, with high pressure valves; mechanical pressure gauges (500 bar); pressure transducers; flowmeter with fittings for high-pressure hoses and sensors equipped with connectors for the data acquisition system. Data were stored digitally in a laptop using the poly-DAQ data acquisition system.

A $70 \mathrm{~mm}$ (outer diameter) hydraulic fracturing straddle packer system (IPI, Australia) rated for 10,000 psi and made using carbon steel and natural rubber was used to carry out the study. A $6.4 \mathrm{~mm}$ model (model: $2340 \mathrm{~N}-$ 04V10) and $9.8 \mathrm{~mm}$ (model: 2X80N-06V10) bore 720 bar working pressure thermoplastic hose of abdex polyflex was used for fluid transmission.

A Hansa flex (model-MVENW08SVA) and flowmeter (10 LPM (litres per minute); model - HO3/4X1/40.26-2.6-T-1MC3PA-AC/3/4-CE; make - Hoffer) were used on the surface. In addition, a downhole pressure transducer (make - Datacan) of 10000 psi and $19 \mathrm{~mm}$ outer diameter was fitted in the straddle system. A high pressure pump (make-Speck, model-NP25/15-500), 10 LPM, 1450 RPM and $14.8 \mathrm{~kW}$ was placed on the surface.

The data acquisition system (make - Polymetra GmbH; model - USB-1608FS PLUS (2016), Sweden) was specially designed for recording data from packer tests. Its graphical real-time representation allows the operator to

Box 1. Description of the data acquisition system

(i) Eight differential input channels.

(ii) Input type: millivolt, volt, milliampere

(iii) 16 bit resolution.

(iv) Accuracy $\pm 0.1 \%$.

(v) USB 2.0 connection to PC.

(vi) Maximum sampling rate: $1 \mathrm{sec} ; 100 \mathrm{~Hz}$. 


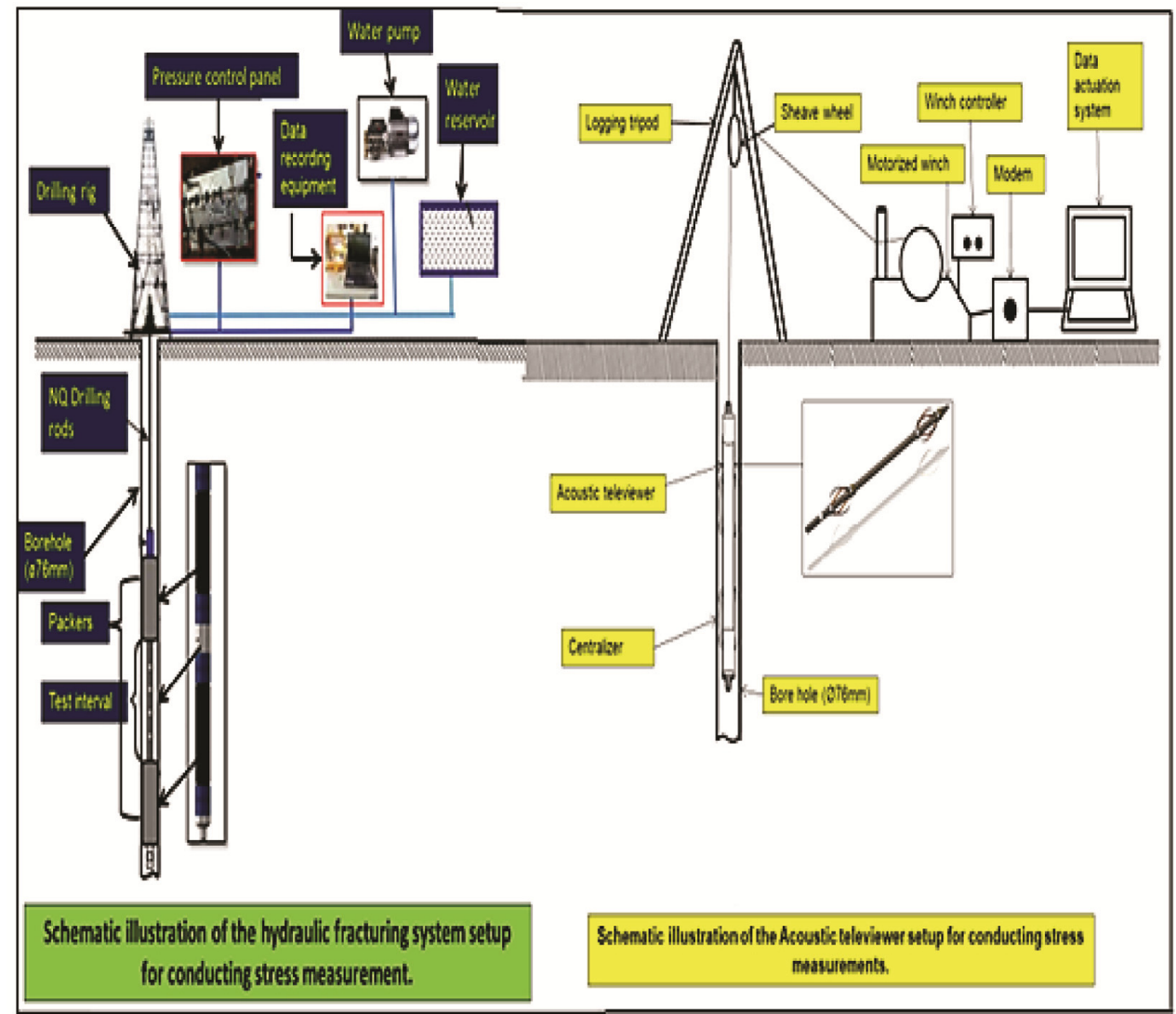

Figure 4. Schematic diagram of hydraulic fracturing experimental set-up.

Table 1. Data acquired at Mandamarri shaft block (MMSB)

\begin{tabular}{lccccc}
\hline BH no. & Depth $(\mathrm{m})$ & $\begin{array}{c}\text { Fracture inclination } \\
\left(\text { deg } 90^{\circ} \text { vertical }\right)\end{array}$ & $\begin{array}{c}\text { Fracture strike } \\
(\mathrm{N}-\mathrm{E}, \mathrm{deg})\end{array}$ & $P_{\text {si }}(\mathrm{MPa})$ & Remarks \\
\hline KK-244B & 472.5 & 80.20 & 330.19 & 11.85 & - \\
& 489.5 & 82.89 & 239.88 & 7.25 & - \\
& 496.5 & 88.79 & 185.41 & 12.19 & Shut-in pressure could not be attained \\
\hline
\end{tabular}

Table 2. Data acquired at Ravindrakhani Newtech (RKNT) dipside block

\begin{tabular}{|c|c|c|c|c|c|}
\hline BH no. & Depth (m) & $\begin{array}{l}\text { Fracture inclination } \\
\left.\text { (deg } 90^{\circ} \text { vertical }\right)\end{array}$ & $\begin{array}{l}\text { Fracture strike } \\
(\mathrm{N}-\mathrm{E}, \mathrm{deg})\end{array}$ & $P_{\text {si }}(\mathrm{MPa})$ & Remarks \\
\hline \multirow[t]{5}{*}{ RKP-801 } & 520.5 & - & - & - & $\begin{array}{l}\text { Shut-in pressure could not be } \\
\text { attained due to presence of coal seam }\end{array}$ \\
\hline & 524.5 & - & - & $\begin{array}{l}18.12 \text { (vertical stress } \\
\text { measured across the } \\
\text { fracture) }\end{array}$ & Encountered horizontal fracture \\
\hline & 527.5 & 40.59 & 252.00 & 15.92 & \\
\hline & 533.5 & 56.61 & 121.78 & 21.03 & \\
\hline & 544.5 & 70.94 & 111.88 & 11.29 & \\
\hline
\end{tabular}

control the tests efficiently as changes in flow and pressure are recognized instantaneously. Box 1 provides a brief description of the system.

High-resolution acoustic borehole televiewer logging was employed to determine several physical properties of the geological formations intersected by boreholes. The information collected may then be utilized to determine the geometry of key subsurface structural discontinuities, and to assess the mechanical properties of the formations surrounding the borehole. The acoustic borehole televiewer was used to detect fractures created by hydraulic fracturing. 


\section{RESEARCH COMMUNICATIONS}

Table 3. Principal stress tensors as evaluated for MMSB

\begin{tabular}{lll}
\hline Parameters & Magnitude and direction \\
\hline Rock cover of 517.55 m and density of rock $=2400 \mathrm{~kg} / \mathrm{m}^{3}($ density determined by laboratory test on core samples & 12.172 & \\
$\quad$ at certain depth obtained from borehole no. KK $244 \mathrm{~B})$ & & $12.444 \pm 0.166$ \\
Major principal horizontal stress $\left(S_{\mathrm{H}}\right)$ & $6.222 \pm 0.083$ \\
Minor principal horizontal stress $\left(S_{\mathrm{h}}\right)$ & $\mathrm{N} 40^{\circ}$ \\
Direction of maximum stability $(\mathrm{N}-\mathrm{E}, \mathrm{deg})$ & 1.022 \\
$S_{\mathrm{H}} /$ Vertical stress $\left(S_{\mathrm{v}}\right)$ & \\
\hline
\end{tabular}

Table 4. Principal stress tensors as evaluated for RKNT dipside block

\begin{tabular}{|c|c|}
\hline Parameters & Magnitude and direction \\
\hline $\begin{array}{l}\text { Rock cover of } 544.5 \mathrm{~m} \text { and density of rock }=2400 \mathrm{~kg} / \mathrm{m}^{3} \text { (density determined by laboratory test on core samples } \\
\text { at certain depth obtained from borehole no. RKP-801) }\end{array}$ & 12.806 \\
\hline Vertical stress $\left(S_{\mathrm{v}}\right)$ at depth of $524.5 \mathrm{~m}$ & 18.12 \\
\hline Major principal horizontal stress $\left(S_{\mathrm{H}}\right)$ & $17.798 \pm 4.736$ \\
\hline Minor principal horizontal stress $\left(S_{\mathrm{h}}\right)$ & $8.899 \pm 2.368$ \\
\hline Direction of maximum stability (N-E, deg) & $\mathrm{N} 20^{\circ}$ \\
\hline$S_{\mathrm{H}} / S_{\mathrm{v}}$ & 1.389 \\
\hline
\end{tabular}

The test zones were selected based on core recovery from the borehole, and the hydro-fracture test assembly was positioned at the required depth to increase the injection pressure for initiation of hydraulic fracture or to reopen the pre-existing fracture. Similar type of fracture initiation was done to reopen the fractures. The tests were conducted from 472.5 to $517.55 \mathrm{~m}$ depth in $\mathrm{BH}$ no. KK244B of MMSB and 520.5 to $544.5 \mathrm{~m}$ depth in BH no. RKP-801 of RKNT dipside block. Figure 4 shows a schematic diagram for execution of the test. Finally, distribution of the direction of maximum horizontal compression and its magnitude were derived from the fracture orientation which is in line with shut-in pressure measured.

Tables 1-4 show results of the tests conducted in both the boreholes.

In this study, the theory, equipment and method of hydraulic fracturing stress measurement used in deep boreholes at the proposed mining blocks of Singareni Collieries are presented. The objective of the study was to determine the major/principal horizontal stress direction derived from hydro-fracturing test in $\mathrm{BH}$ no. 244B drilled in sector-B of MMSB and in BH no. RKP-801 drilled in the RKNT dipside block to throw light on the designing of layouts of galleries/panels proposed during mining. The galleries/panels aligned parallel to the major/ principal horizontal stress direction attained stability, whereas their perpendicular alignment to the direction of stress resulted in roof hazards.

A good understanding of the in situ stress field combined with knowledge of rock-mass properties and structure is key to the proper design of ground support. Roof instability under some stress conditions may be avoided if the immediate roof stresses are taken into consideration in support design.
1. Fairhurst, C., In situ stress determination an appraisal of its significance in rock mechanics. In Proceedings of the International Symposium on Rock Stress and Rock Stress Measurements, Stockholm, Centek Publ., Lulea, Sweden, 1986, pp. 3-17.

2. Haimson, B., A simple method for estimating in situ stresses at great depths. In Field Testing and Instrumentation of Rock (ed. Clark, G.), West Conshohocken, ASTM International, PA, 1974, pp. 156-182; https://doi.org/10.1520/STP32150S

3. Rummel, F., Stresses and Tectonics of the Upper Continental Crust-A Review, International Society for Rock Mechanics and Rock Engineering, 1986.

4. Amedi, B. and Stephanson, O., Rock Stress and its Measurement, Chapman \& Hall Publishers, London, UK, 1997.

5. Bigby, D. N., Cassie, J. W. and Ledger, A. R., Absolute stress and stress change measurements in British coal measures. In Proceedings of ISRM Conference on Rock Characterization. Proceedings of ISRM Symposium: Eurock'92, Chester, 14-17 September 1992, pp. 390-395.

6. Cornet, F. H. and Valette, B., In situ stress determination from hydraulic injection test data. J. Geophys. Res., 1984, 89(13), $11527-11537$

7. Cornet, F. H., Stress determination from hydraulic tests on preexisting fractures - the H.T.P.F. method. In Proceedings of the International Symposium Rock Stress and Rock Stress Measurements, CENTEK Publ, Lulea, Sweden, 1986, pp. 301-311.

8. User's Manual, Mesy's Hydrofrac pressure and flow rate data analysis software, Mesy GMBH, Germany, 1993.

9. User's Manual, Gensim and Plane Software, Mesy GMBH, Germany, 1993.

10. Internal Reports and Communications of NIRM.

Received 7 March 2019; accepted 10 June 2020

doi: $10.18520 / \mathrm{cs} / \mathrm{v} 119 / \mathrm{i} 6 / 1027-1030$ 